RESEARCH ARTICLE

\title{
Influence of Sett Treatments on Biochemical, Weed, Physiological Parameters and Nutrient Uptake of Bajra Napier Hybrid Grass [CO (BN)5]
}

\author{
Varshini S $\mathrm{V}^{*}$ and Jayanthi $\mathrm{C}$ \\ Department of Agronomy, Tamil Nadu Agricultural University, Coimbatore-3
}

Corresponding author mail id: varshuagri08@gmail.com

A field experiment was conducted at the Department of Agronomy, Tamil Nadu Agricultural University, Coimbatore, to study the influence of sett treatment on biochemical parameters, weed parameters, physiological parameters and nutrient uptake of bajra Napier hybrid grass. The results of the experiment indicated that on biochemical parameters, sett treatment with water (12 hours soaking fb 24 hours incubation) $\left(\mathrm{S}_{1}\right)$ recorded higher reducing sugars $(28.89 \mathrm{mg} / \mathrm{g})$, total sugar $(34.83 \mathrm{mg} / \mathrm{g})$ and starch content $(45.83 \mathrm{mg} / \mathrm{g})$. Whereas the lower non reducing sugar content $(5.94 \mathrm{mg} / \mathrm{g})$ and total phenolics content $(1.65 \mathrm{mg} / \mathrm{g})$ were also observed with sett treatment with water (12 hours soaking fb 24 hours incubation) $\left(\mathrm{S}_{1}\right)$. Similarly, on weed parameters, significantly lower weed density (9.90 No. $\left./ \mathrm{m}^{2}\right)$ and weed dry weight $\left(12.92 \mathrm{~g} / \mathrm{m}^{2}\right)$ was recorded with sett treatment with water (12 hours soaking fb 24 hours incubation) ( $\left.\mathrm{S}_{1}\right)$. On physiological parameters, significantly higher leaf area index (28.98), relative water content $(87.85 \%)$ was registered with water (12 hours soaking fb24 hours incubation) $\left(\mathrm{S}_{1}\right)$. Among sett treatments, water (12 hours soaking fb24 hours incubation) $\left(\mathrm{S}_{1}\right)$ had registered higher nitrogen (192.8 $\mathrm{kg} \mathrm{ha}^{-1}$ ), phosphorus (33.0 $\mathrm{kg} \mathrm{ha}^{-1}$ ) and potassium (112.9 kg ha-1) uptake.
\end{abstract}

Keywords: Sett treatments; Biochemical; Weed;Physiological parameters; Nutrient uptake; Bajra napier hybrid grass.

\section{INTRODUCTION}

India, with $2.3 \%$ share of global geographical area, supports nearly $10.7 \%$ of the livestock population of the world (Chellamuthu et al., 2011).Even though it is first in milk production, the productivity of Indian livestock is very low (1538 kg/yr) compared to the world average ( $2238 \mathrm{~kg} / \mathrm{yr}$ ), which can be attributed to malnutrition or undernutrition.To provide sufficient milk to the ever-growing population, there is a need to increase the current milk production of 132 m.t to 160 m.t by 2020 and to achieve this, 825 m.t of green fodder, 494 m.t of dry fodder and 54 m.t of concentrates are required. However, at present, India is facing a shortage of $36 \%$ of green fodder, $11 \%$ of dry crop residues and $44 \%$ of concentrates Increase in the area under fodder crops seems difficult, because of severe competition from food crops.This forced majority of the farmers to feed their animals on poor quality crop residue or wild grasses (Hegde, 2012). Aher et al.(2003) reported that about $97 \%$ of available fodder is of very poor quality, which 
along with inadequate availability causes a decline in animal health and milk productivity. The demand can be met by cultivating bajra Napiar hybrid grass in a larger area.

Bajra Napier hybrid grass CO (BN) 5 is an interspecific hybrid between fodder Bajra IP 20594 (Pennisetum glaucum) and Napier grass FD 437 (P. Purpureum Schumach). Generally, its vegetative propagation is through stem cuttings (Singh et al., 2011). But, multiplication and sale of planting material have major constraints, such as high transportation cost due to high volume, damage to the standing crop from where rooted slips are taken out, involvement of high labor cost, etc. (Vijay et al., 2018).

The large planting material requirement poses a huge problem in transport, handling and storage of sett material and undergoes rapid deterioration, thus reducing the viability of buds and subsequently their sprouting, which also increases the production cost. One alternative to reduce the mass and improve setting quality is to reduce sett size with treatment (Jain et al., 2010). Sett treatment with growth-promoting chemicals and water might hasten up germination-related metabolic process (Jain et al., 2011). With the deficit of fodder increasing fodder requirement every year, it is essential to develop efficient and suitable sett treatment on physiological and nutrient uptake of bajra napier grass.

Therefore, this study was undertaken to assess the performance of different sett treatments on biochemical and physiological parameters, weed growth and nutrient uptake of bajra Napier hybrid grass.

\section{MATERIALS AND METHODS}

A field experiment was conducted during 2018-2019 in Field No. 75 at Eastern block farm of Department of Agronomy, Tamil Nadu Agricultural University, Coimbatore. The soil in the experimental field is sandy clay loam in texture. Climatic conditions that prevailed during the cropping period were $68.6 \mathrm{~mm}$ of rainfall, maximum and minimum temperatures of $31^{\circ} \mathrm{C}$ and $23^{\circ} \mathrm{C}$ and relative humidity of 86 and $57 \%$ was observed during morning and evening respectively based on the data provided by Agroclimate research centre, Tamil Nadu Agricultural University. The chemical analysis of soil indicated that the soil was low in available nitrogen (205 kg ha-1), high in available phosphorus (33 kg ha-1), and high in available potassium (769 kg ha-1). It was moderately alkaline in reaction ( $\mathrm{pH} 8.49$ ) with $0.55 \mathrm{dSm}^{-1}$ electrical conductivity. The organic carbon content was $0.57 \%$. The variety adapted for the study was CO (BN) 5 bajra Napier hybrid grass.

The experimental field was laid out in a randomized block design (RBD) with thirteen treatments and two replications. The treatment comprised of thirteen sett treatments viz, water soaking for 12 hours and 24 hours incubation $\left(T_{1}\right)$, water soaking for 30 minutes $\left(T_{2}\right)$, hot water soaking at $40^{\circ} \mathrm{C}$ for 20 minutes $\left(T_{3}\right)$, cowdung slurry $(1: 1)$, soaking for 30 minutes $\left(T_{4}\right)$, panchagavya (3\%) soaking for 30 minutes $\left(T_{5}\right)$, panchagavya $(5 \%)$ soaking for 30 minutes $\left(T_{6}\right)$, beejamruth (soaking concentrated solution for 30 minutes) $\left(\mathrm{T}_{7}\right)$, beejamruth (50\% dilution) soaking for 30 minutes ( $\left.\mathrm{T}_{8}\right)$, GA3 (5 ppm) soaking for 15 minutes ( $\left.T_{9}\right)$, GA3 (10 ppm) soaking for 15 minutes ( $\left.T_{10}\right)$, ethrel (50 ppm) soaking for 15 minutes ( $\left.T_{11}\right)$, ethrel (100 ppm) soaking for 15 minutes ( $\left.T_{12}\right)$ and control (without sett treatment) ( $\left.T_{13}\right)$. The field was thoroughly ploughed and applied with recommended dose of NPK 75:50:40 kg ha-1 as basal and subsequently, $75 \mathrm{~kg}$ $\mathrm{ha}^{-1}$ of nitrogen was applied at 30 DAP. The single budded setts were treated as per the treatment schedule and planted vertically in their respective plots with a spacing of $60 \times 50 \mathrm{~cm}$. 
On biochemical parameters, reducing sugar of planting material was estimated by using the Nelson-Somogyi method suggested by Somogyi (1952) and the results are expressed in $\mathrm{mg} / \mathrm{g}$ of fresh weight. Further, the amount of non-reducing sugar of planting material was arrived at by subtracting reducing sugar from total sugar and expressed as $\mathrm{mg} / \mathrm{g}$ of fresh weight. Total soluble sugar amount and total starch content of the planting material were estimated by the anthrone method suggested by Hedge and Hofreiter (1962) and the results were noted as $\mathrm{mg} / \mathrm{g}$ of fresh weight. Total phenolics content of planting material was obtained by the method suggested by Mallick and Singh (1980) and the measured values were expressed as $\mathrm{mg} / \mathrm{g}$ of fresh weight. The IAAO activity of planting material was analyzed before planting and two days after sprouting by the method suggested by Parthasarathy et al. (1970) by using Garden-Weber reagent. The enzyme activity was expressed as $\mu \mathrm{g}$ of unoxidized auxin/g/hr.

On physiological parameters, leaf area index was measured by standard procedure suggested by (Shanmugasundaram, 1980). Relative water content (RWC) of fully expanded fourth leaf of bajra Napier hybrid grass was determined by the method suggested by Barrs and Weatherley (1962). Chlorophyll index was measured by using a SPAD-502 meter (Peng et al., 1992). For weed parameters, the total weed density of grasses, sedges, broad-leaved weeds in each plot were recorded by using quadrate in four places at random and the mean values were expressed in no./ $\mathrm{m}^{2}$. To obtain the total weed dry weight, the weeds removed from each treatment plot from the sampling area were air-dried and then oven-dried at $80^{\circ} \pm 5^{\circ} \mathrm{C}$ to obtain a constant weight and expressed as $\mathrm{g} / \mathrm{m}^{2}$. Total nitrogen uptake was analyzed by the standard procedure of micro Kjeldahl method (Humphries, 1956). Similarly, phosphorus and potassium uptake were analyzed by triple acid digestion method (Jackson, 1973) and expressed in kgha-1.

The statistical analysis for weed, physiological parameters and nutrient analysis were done using the statistical method of randomized block design. For biochemical parameters, the data was analyzed using completely randomized block design. Wherever the results were significant, the critical difference at $5 \%$ level of significance was worked out as given by Gomez and Gomez (1984).

\section{RESULTS AND DISCUSSION}

\section{Biochemical parameters}

The results (Fig 1.) on the changes in the reducing sugar content due to various sett treatments revealed significant increase in reducing sugar over untreated setts of bajra napier hybrid grass. Sett treatment with water (12 hours soaking fb 24 hours incubation) $\left(\mathrm{S}_{1}\right)$ registered significantly higher reducing sugars of $28.89 \mathrm{mg} / \mathrm{g}$. This might be due to higher sucrose synthase activity in the nodes, which improved the reducing sugars of glucose and fructose. This finding was supported by Jain et al. (2011) and reported that sett treatment increased the reducing sugar content, which acts as food material for the sprouted buds due to higher transportation of hexoses towards the growing apical meristem. Subsequently, Warle et al. (2015) also revealed that soaked sorghum seeds improved reducing sugars by converting maltose and fructose to glucose by the activities of $\alpha$ and $\beta$-amylase enzymes. But, significantly lesser level of reducing sugar $(16.72 \mathrm{mg} / \mathrm{g})$ was recorded with control (without sett treatment) $\left(\mathrm{S}_{13}\right)$.

But lower non-reducing sugar content of $5.94 \mathrm{mg} / \mathrm{g}$ was recorded with water treatment (12 hours soaking fb 24 hours incubation) $\left(S_{1}\right)$. This might be due to improved hydrolysis, which converted the non- 
reducing sugars into reducing sugar and resulted in lower non-reducing sugar. This finding was supported by Noorbakhshian et al. (2011) who opined that enhanced alpha amylase activity during the hydro priming resulted in increased starch hydrolysis, thus improving the reducing sugar with reduced content of non reducing sugars. Significantly higher non-reducing sugar of $7.97 \mathrm{mg} / \mathrm{g}$ was observed with control (without sett treatment) $\left(S_{13}\right)$.

Similarly, higher total sugar of $34.83 \mathrm{mg} / \mathrm{g}$ was registered with water treatment (12 hours soaking fb24 hours incubation) $\left(\mathrm{S}_{1}\right)$. This might be due to enhanced activity of $\alpha$-amylase by proper hydration during imbibition, resulting in increased total sugar content. This result is in agreement with the findings of Basra et al. (2005), who opined that seed treatment of rice with 24 hours water soaking converted the complex starch into increased content of total sugars by hydrolysis. Subsequently, Matias et al. (2018) stated that sunflower seeds treated with water improved the total sugar content during germination. But, setts without treatment (control) $\left(\mathrm{S}_{13}\right)$ recorded significantly lower total sugar content of $24.69 \mathrm{mg} / \mathrm{g}$.

Higher starch content of $45.83 \mathrm{mg} / \mathrm{g}$ was observed with water treatment (12 hours soaking fb24 hours incubation) $\left(\mathrm{S}_{1}\right)$. This might be due to improved water imbibition in setts and enhanced hydrolytic process, thus resulting in higher starch content. Wheat seeds soaked with water improved the starch content five times greater than the unsoaked seeds (Kashem et al., 1995). These results agree with the findings of Kalpana et al. (2015), who opined that seed treatment with water increased the starch content due to induced hydrolysis of reserve polysaccharides or rapid utilization of total soluble starch. The lowest starch content of $28.54 \mathrm{mg} / \mathrm{g}$ was recorded with control (without sett treatment) $\left(\mathrm{S}_{13}\right)$.

Water treatment (12 hours soaking $f b 24$ hours incubation) $\left(S_{1}\right)$ recorded the lowest total phenolic content of $1.65 \mathrm{mg} / \mathrm{g}$. This might be due to increased peroxidase activity. This was in agreement with the findings of Solomon and Srivastava (1990) who recorded lower content of phenol in sprouted buds. The higher phenol content showed inhibitory effect on the sprouting of buds. This result is in accordance with the findings of Hameed et al. (2013). Noticeably, the highest total phenolic content of $3.93 \mathrm{mg} / \mathrm{g}$ was registered with control (without sett treatment) $\left(\mathrm{S}_{13}\right)$.

On sett treatments, water treatment (12 hours soaking fb 24 hours incubation) $\left(\mathrm{S}_{1}\right)$ recorded significantly lower IAAO activity with higher unoxidized auxin (39.5 $\mu \mathrm{g}$ of unoxidized auxin/g/hr). This might be due to improved water imbibitions, which activate the auxin biosynthetic enzymes and enhanced hydrolysis of phenolics which might have decreased the IAAO activity. This result is in agreement with the findings of Bansal and Nanda (1982). The decreased activity of IAAO retained more amount of auxin in the nodal region and in the developing buds might be responsible for rapid and better germination and further growth of buds. Significantly higher IAAO activity with lower unoxidised auxin (23.4 $\mu \mathrm{g}$ of unoxidized auxin/g/hr) was registered with control (without sett treatment) $\left(S_{13}\right)$. Similar trend was noticed at two days after sprouting also.

\section{Weed parameters}

Significantly lower weed density $\left(9.90 \mathrm{No} . / \mathrm{m}^{2}\right)$ and weed dry weight $\left(12.92 \mathrm{~g} / \mathrm{m}^{2}\right)$ of were recorded with water (12 hours soaking fb 24 hours incubation) $\mathrm{S}_{1}$ (Fig 2 ). This was mainly due to improved early sprouting and establishment percentage that reduced the weed density and weed dry weight was also indicated by effective utilization of resources available for crop growth Takim et al. (2014). Further, 
Singh et al. (2012) supported this, who revealed seed treatment with water resulted in lower weed density and weed dry weight. Significantly higher weed density (13.06 No./m²) and weed dry weight $\left(17.31 \mathrm{~g} / \mathrm{m}^{2}\right)$ were recorded in control $\left(\mathrm{S}_{13}\right)$. This might be because of the longer time taken for sprouting and establishment; space left free for weed growth due to poor plant population and less competition exerted by crops for resources like light, moisture and nutrients. This finding is further supported by Singh et al. (2012).

\section{Physiological parameters}

On physiological parameters, significantly higher leaf area index (28.98) was recorded with water treatment (12 hours soaking fb 24 hours incubation) ( $\mathrm{S}_{1}$ ) (Fig 3). This was mainly due to an increase in leaf length and width, which ultimately increased the leaf area of the plant. Wahid et al. (2008) also confirmed that the increased leaf area was because of the induction of metabolic activities in the buds caused due to the treatment of setts with water. The high leaf area index could also be attributed to higher photosynthetic activity due to water treatment since leaf area increases due to greater light interception associated with photosynthetic evolution (Mir et al., 2010). But significantly lower leaf area index (19.85) was recorded in control (without sett treatment) $\left(\mathrm{S}_{13}\right)$.

Similarly, on relative water content, water treatment (12 hours soaking $f b 24$ hours incubation) $\left(\mathrm{S}_{1}\right)$ registered significantly higher relative water content $(87.85 \%)$. This might be due to the early establishment of a root system that improved the water uptake, resulting in increased relative water content. But lower relative water content (70.54 \%) was observed with control (without sett treatment) $\left(\mathrm{S}_{13}\right)$. On chlorophyll content, sett treatment showed non-significant difference. These results are similar to the findings of Shah (2007) who reported that seed priming in different planting methods showed nonsignificant differences in chlorophyll content. Further, these results agree with the findings of Mahboob et al. (2015) and Ghasemi et al. (2020).

\section{Nutrient uptake}

Significantly higher nitrogen (192.8 $\left.\mathrm{kg} \mathrm{ha}^{-1}\right)$, phosphorus (33.0 kg ha-1) and potassium (112.9 kg


was at par with beejamruth $\left(\mathrm{S}_{7}\right)$, which recorded $\mathrm{N}$ uptake of $186.5 \mathrm{~kg}^{-1}$, P uptake of $31.1 \mathrm{~kg} \mathrm{ha}^{-1}$ and $\mathrm{K}$ uptake of (106.4 $\left.\mathrm{kg} \mathrm{ha}^{-1}\right)$. This is mainly because of early and improved plant growth especially roots, which might have taken more nutrient resulting in higher plant growth (Nouman et al., 2012). The result is in agreement with the findings of Kushwaha et al. (2018) who reported that seed treatment with water soaking significantly increased the nutrient uptake. The lower nitrogen (105.2 kg ha-1), phosphorus (11.9 kg $\mathrm{ha}^{-1}$ ) and potassium (68.5 $\left.\mathrm{kg} \mathrm{ha}^{-1}\right)$ uptake were registered with control (without sett treatment) ( $\left.\mathrm{S}_{13}\right)$. This might be due to poor root growth and increased weed population, which might have created competition for resources and which in turn, reduced the nutrient uptake (Farooq and Basra, 2011). This finding is further supported by Umair et al. (2011).

\section{CONCLUSION}

It is concluded from the study that, sett treatment with water (12 hours soaking fb 24 hours incubation) $\mathrm{S}_{1}$ recorded higher biochemical parameters, physiological parameters and nutrient uptake with 
reduced weed density and weed dry weight on bajra Napier hybrid grass CO (BN) 5. Also, reduce the planting material requirements can be reduced by using single budded setts.

\section{REFERENCES}

Bansal, M.P. and K.K. Nanda. 1982. IAA oxidase activity in relation to IAA effects on rooting stem cuttings. Biochemie und Physiologie der Pflanzenc., 177 (3):216-221.

Barrs, H.D. and P.E. Weatherley. 1962. A re-examination of the relative turgidity technique for estimating deficit in leaves. Aus. J. of Biol Sci., 15 (3):413-428.

Basra, S.M.A., M. Farooq, R. Tabassam. and N. Ahmad. 2005. Physiological and biochemical aspects of presowing seed treatments in fine rice (Oryza sativa, L.). Seed Sci. Technol., 33 (3):623-628.

Chellamuthu, V., P. Saravanane and S. G. Paradis. 2011. Evaluation of bajra napier hybrid grass cultivars under coastal ecosystem of Karaikal, Puducherry Union Territory. Madras Agric. J., 98 (7/9): 253254.

Farooq, M. and S.M.A. Basra. 2011. Rice cultivation by seed priming. DAWN Business; 03 January, 2011.

Ghasemi, N. H. Omidi. and A. Bostani. 2020. Morphological properties of (Catharanthusroseus L.) seedlings affected by priming techniques under natural salinity stress. J. Plant Growth Regul., 1-8.

Gomez, K.A. and A.A Gomez. 1984. "Analysis of data from a series of experiments. Statistical Procedures for Agricultural Research. $2^{\text {nd }}$ ed. New York: J. Wiley, 316-356.

Hameed, A., M. A. Sheikh, A. Hameed, T. Farooq, S.M.A. Basra. and A. Jamil. 2013. Chitosan priming enhances the seed germination, antioxidants, hydrolytic enzymes, soluble proteins and sugars in wheat seeds. Agrochimica, 57 (2):97-110.

Hedge, J.E. and B.T. Hofreiter. 1962. In Carbohydrates Chemistry. (17th eds. Whistler, RL and JN BeMiller) Academic Press, New York.

Humphries, E.C. 1956. Mineral components and ash analysis. Modern methods of plant analysis. Springer Berlin Heidelberg, 1:468-502.

Jackson, M.L. 1973. Soil Chemical Analysis. Prentice hall of India Private Limited, New Delhi:67-214.

Jain, R., S. Solomon, A.K. Shrivastava. and A. Chandra. 2011. Effect of ethephon and calcium chloride on growth and biochemical attributes of sugarcane bud chips. Acta physiol. Plant., 33 (3):905-910.

Kalpana, M.H., A. Khan, A.K. Singh, K.N. Maurya, R.K. Mubeen, U. Yadava, A.K. Singh. and R. Gautam. 2015. Effect of different seed priming treatments on germination, growth, biochemical changes and yield of wheat varieties under sodic soil. Int. J. Sci. Res., 4 (7):306-3010.

Kashem, M.A., N. Sultana, S.C. Samanta. and A.M.A. Kamal. 1995. Starch, sugar, amylase and invertase activity in the germinating seeds of modern wheat varieties. J. Natl. Sci. Council Srilanka, 23 (2):55-61.

Kushwaha, A., A. H. Khan, R. K. Yadav, N. Nehal. and N. Sharma. 2018. Role of seed priming on biochemical changes and NPK uptake of rice (Oryza sativa L.). J. Pharmacogn. Phytochem., 2:1-4. 
Mahboob, W., H.U. Rehman, S.M.A. Basra, I. Afzal, M.A. Abbas, M. Naeem and M. Sarwar. 2015. Seed priming improves the performance of late sown spring maize (Zea mays) through better crop stand and physiological attributes. Int. J. Agric. Biol., 17 (3):491-498.

Mallick, C.P. and M.B. Singh. 1980. In:Plant Enzymology and Histo Enzymology, Kalyani Publishers, New Delhi:286.

Matias, J.R., S.B. Torres, C.C. Leal, M.D.S. Leite. and S. Carvalho. 2018. Hydropriming as inducer of salinity tolerance in sunflower seeds. Rev. Bras. Eng. Agríc. Ambient., 22 (4):255-260.

Mir, M.R., M. Mobin, N.A. Khan, M.A. Bhat, N.A. Lone, K.A. Bhat, S.M.Razvi S.A.Wani, N. Wan, S. Akhter and S. Rashid. 2010. Crop response to interaction between ethylene sources and nitrogen with special reference to oilseed crops. J. Phytol., 2 (10):25-33.

Noorbakhshian, S.J., M. Nabipour, M. Meskar bashee. and R. Amooaghaie. 2011. Evaluation of germination and biochemical indexes of sainfoin hydroprimed seed. Am-Eurasian J. Agric. Environ. Sci., 11 (5):671-678.

Nouman, W., S. M. A. Basra, M. T. Siddiqui, R. A. Khan. and S. Mehmood. 2012. Seed priming improves the growth and nutritional quality of rangeland grasses. Int. J. Agric. Biol., 14(5).

Parthasarathy, K., D.R.C. Balu and P.S. Rao. 1970. Studies on sandal spur VII. Polyphenol oxidase activity and metabolism of sandal (Santalum album) in healthy and diseased. In Proceeding of the Indian Academy of Science 72:277-284.

Peng, S., F.V. Garcia, R.C. Laza and K.G. Cassman. 1992. Leaf thickness affects the estimation of leaf N using a chlorophyll meter. IRRI Newsletter, 17 (6):19-20.

Shanmugasundaram, U.S. 1980. Studies on association of perennial grass (NB - 21) legume (Lucerne) mixed on the forage yield and quality. Ph.D. (Agri.,), Thesis, Tamil Nadu Agricultural University, Coimbatore.

Singh, C.V., B. C. Ghosh, V. D. Shukla, D. Maiti. and M. Variar. 2012. Effect of seed treatment and weed management practices on the growth of crop and weeds and productivity of upland rice. Proc. of

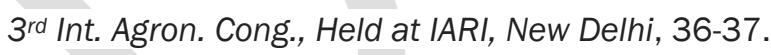

Solomon, S. and K.K. Srivastava. 1990. Effect of phenolic compounds on cane germination and early development. Sugarcane, 1:11-12.

Somogyi, M. 1952. Notes on sugar determination. .J. Biol. Chem., 200:245-247.

Takim, F.O. and M.A. Suleiman. 2017. Impact of plant population and weed control methods on the growth, yield and economic potential of sugarcane (Saccharum officinarum, L.) cultivation. Planta Daninha, 35:1-11.

Takim, F.O., O. Fadayomi, M.A. Alabi. and O.J. Olawuyi. 2014. Impact of natural weed infestation on the performance of selected sugarcane varieties in the southern Guinea savanna of Nigeria. Ethiopian Journal of Environmental Studies and Management, 7 (3):279-288. 
Umair, A., S. Ali, R. Hayat, M. Ansar and M.J. Tareen. 2011. Evaluation of seed priming in mung bean (Vignaradiata) for yield, nodulation and biological nitrogen fixation under rainfed conditions. Afr. J. Biotechnol., 10: 18122-18129.

Wahid A., A. Noreen, S.M.A. Basra, S.Gelani, and M. Farooq. 2008. Priming-induced metabolic changes in sunflower (Helianthus annuus) achenes improve germination and seedling growth. Bot. Stud., 49 (2):343-350.

Warle, B.M., C.S. Riar. and S.S. Gaikwad, V.A. Mane. and B.K. Sakhale. 2015. Effect of germination on nutritional quality of sorghum. Int. J. Curr. Res., 7 (5): 16029-16033.

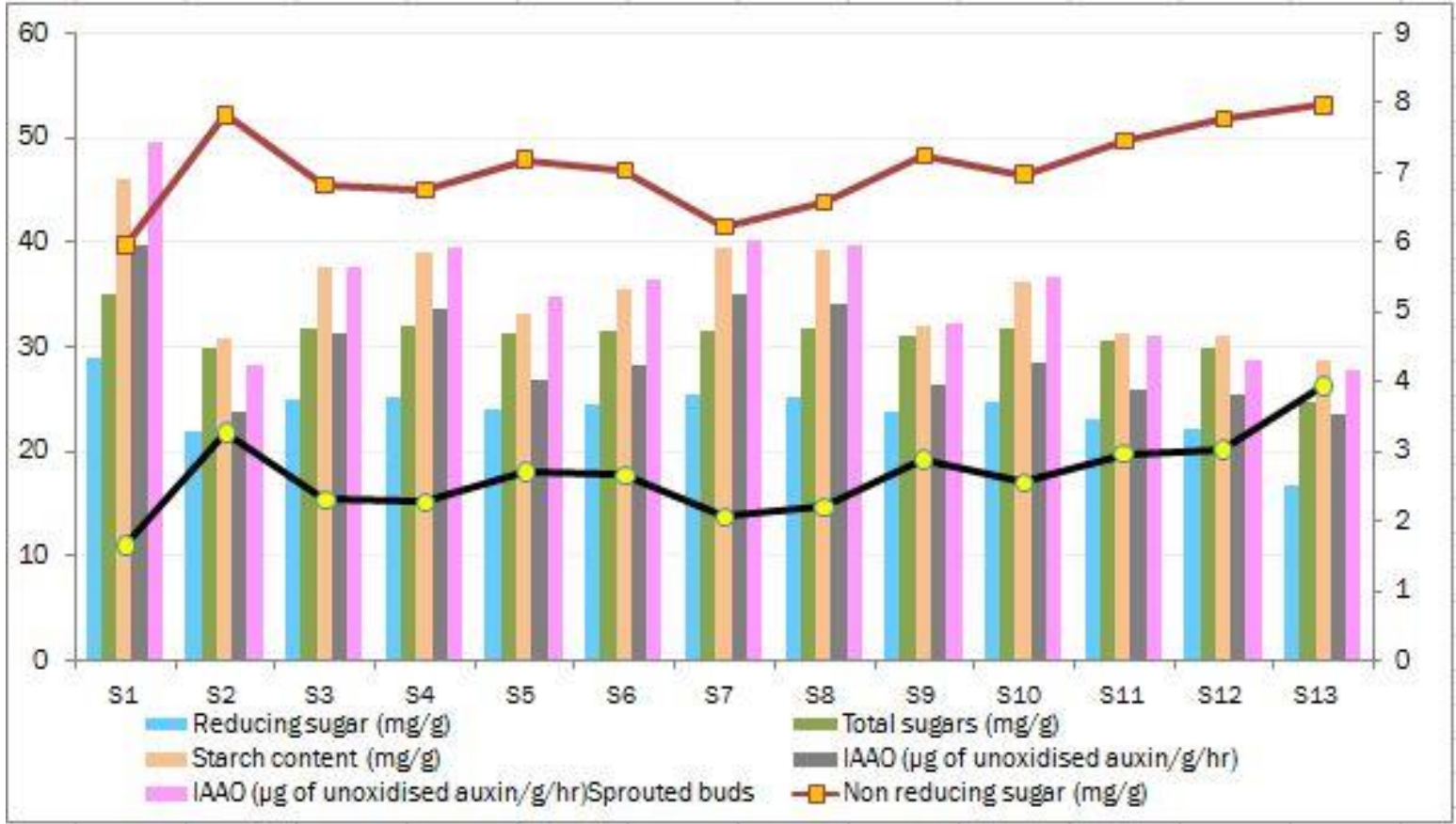

Figure 1. Effect of sett treatments on biochemical parameters of B. N. hybrid grass [CO (BN) 5] 


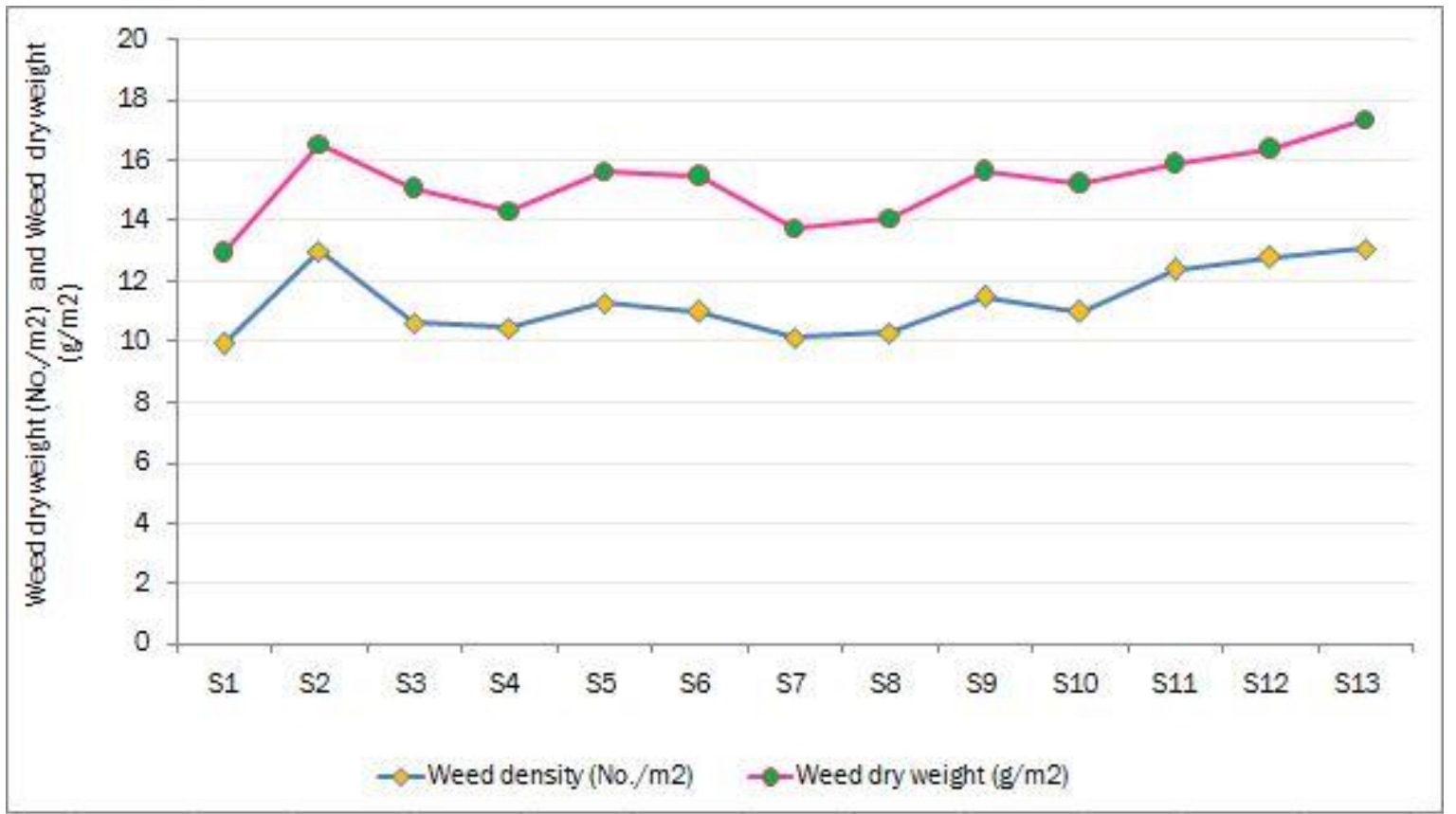

Figure 2. Effect of sett treatments on weed parameters on B. N. hybrid grass [CO (BN) 5] 


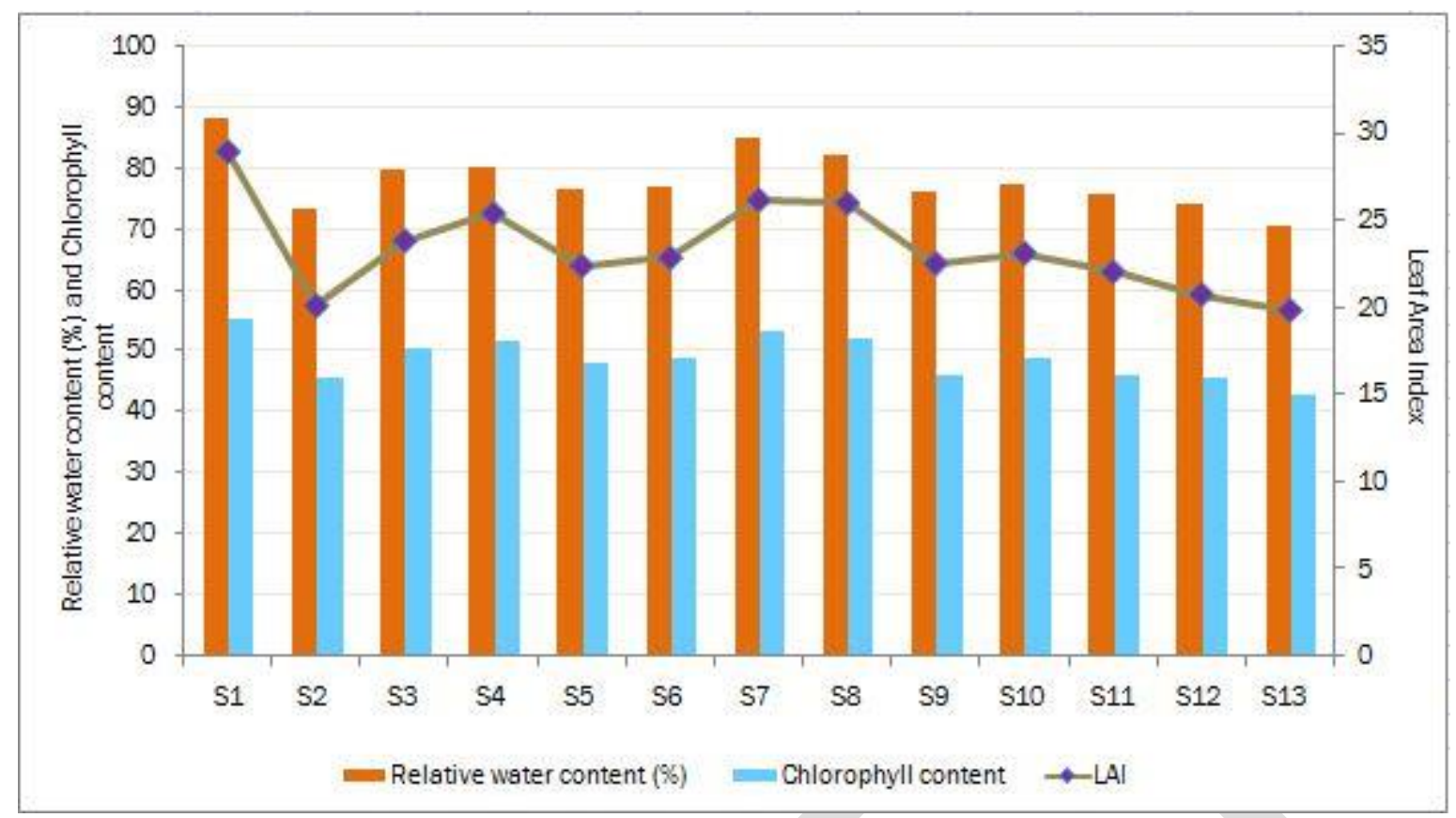

Figure 3. Effect of sett treatments on physiological parameters on B. N. hybrid grass [CO (BN)5] 


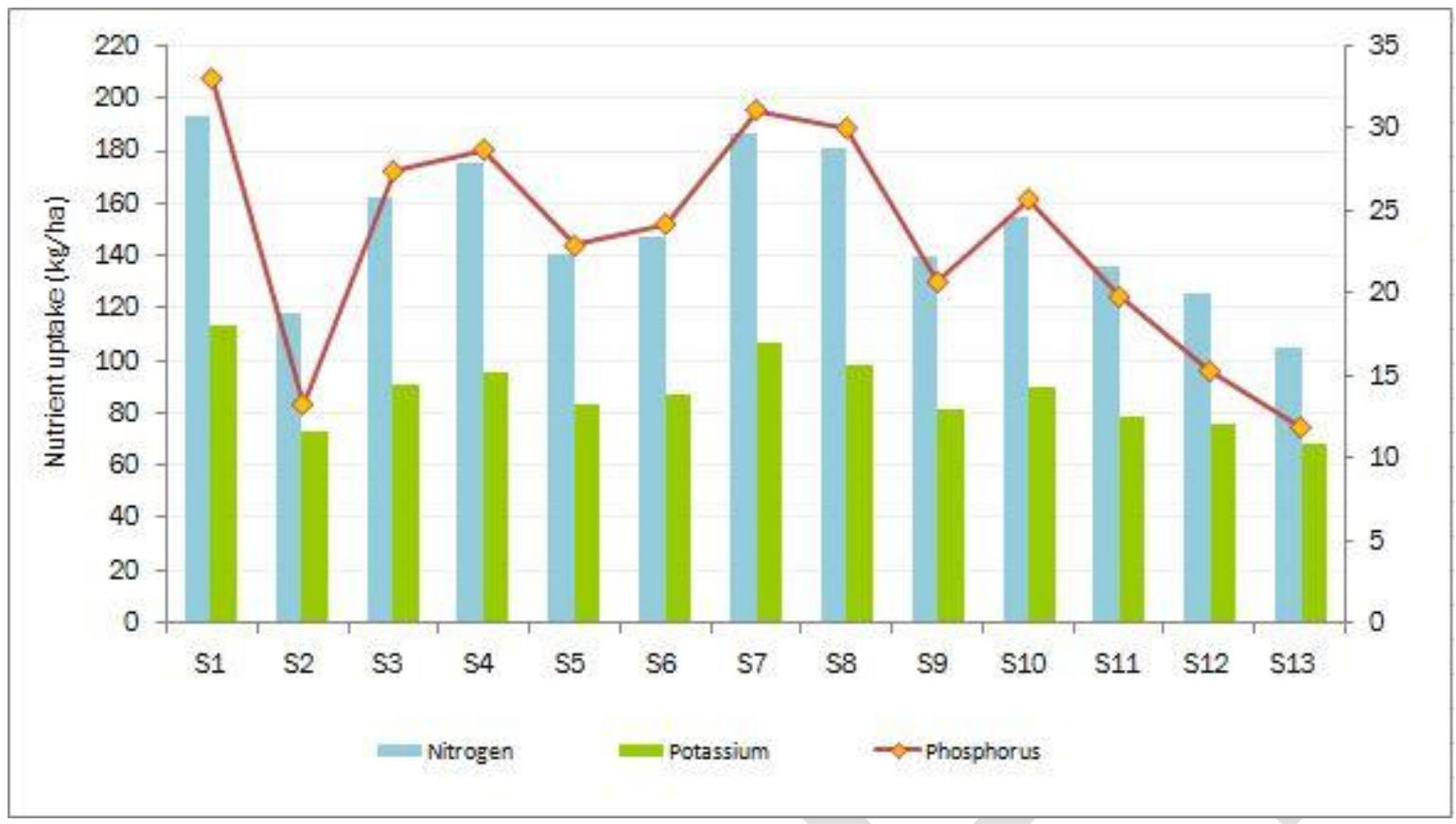

Figure 4. Effect of sett treatments on nutrient uptake (kgha-1) on B. N. hybrid grass $\mathrm{CO}$ (BN) 5 